УДК 070.48:655.527-022.218«192/193»

Вакульчук Ольга Анатоліївна, кандидат історичних наук, завідувачка відділу пресознавства Національної бібліотеки України імені В. І. Вернадського o-vakulchuk@ukr.net ORCID: 0000-0003-4171-3886

\title{
СТІННІ ГАЗЕТИ ЯК РІЗНОВИД РАДЯНСЬКИХ БАГАТОТИРАЖНИХ ВИДАНЬ (20-30 рр. ХХ ст.)
}

\begin{abstract}
Мета роботи - охарактеризувати стінні газети як прототип $і$ різновид окремого виду радянської газетної періодики - багатотиражних газет, які виникають у 20-х роках ХХ ст. $i$ розвиваються у 30-х роках у системі друку СРСР та УСРР під час становлення тоталітарної системи. Методологічним базисом роботи обрано принцип історизму, методи - історикохронологічний, порівняльний, джерелознавчого аналізу та синтезу. Наукова новизна: дослідження стінних газет як виду радянської періодики здійснюється вперше. Висновки. Стінні газети як явище радянської доби, оперативні інформаиійні засоби виникли у 1920-х роках та отримали сприятливі умови для розвитку у 1930-х у системі друку СРСР та УСРР за ідеологічним сценарієм радянськоі влади. Підтримуючи розвиток стінних газет, радянська влада надавала ивому виду періодики роль знаряддя впливу на формування свідомості радянських людей і позиціонувала їх як форму активності, спрямовану на побудову сочіалістичної держави та «сочіалістичної демократії» $i$ підтримку зміцнення та згуртованості колективів на виконання робочих завдань. Велика популярність стінних газет в умовах становлення тоталітарного режиму пояснювалася їх тісним зв 'язком з колективами, котрі випускали ці газети $i$, попри необхідність дотримання ідеологічних настанов, матеріали стіннівок містили інформацію про повсякденне життя колективів, характеризувалися наявністю критичних, гумористичних і сатиричних текстів, наближених до життя людей, а також значного ілюстративного матеріалу.
\end{abstract}

Ключові слова: стінні газети, багатотиражні газети, преса, періодичність, УСРР.

Вакульчук Ольга Анатольевна, кандидат исторических наук, заведующая отделом прессоведения Национальной библиотеки Украины имени В. И. Вернадского

\section{СТЕННЫЕ ГАЗЕТЫ КАК РАЗНОВИДНОСТЬ СОВЕТСКИХ МНОГОТИРАЖНЫХ ИЗДАНИЙ (20-30 гг. ХХ ст.)}

Цель работы - охарактеризовать стенные газеты как прототип и разновидность многотиражных газет - особого вида советской газетной периодики, возникших в системе печати СРСР и УССР в 1920-е годы и продолживших своё развитие в 1930-е - в период становления тоталитарной системы. Методологическим базисом работы стал принцип историзма, методы - историко-хронологический, сравнения, источниковедческого анализа и синтеза. Научная новизна состоит в том, что исследование стенных газет как вида советской периодики проводится впервые. Выводы. Стенные газеты как феномен советского времени, оперативные средства информации возникли в 1920-е г2. и получили благоприятные условия для существования в 1930-е в системе печати СССР и УССР и развивались по идеологическому сиенарию советской власти. Поддерживая развитие стенных газет, советская власть отводила этому виду периодики роль орудия влияния на формирование сознания советских людей и позиционировала их как форму активности масс, направленную на строительство соииалистического государства и «соииалистической демократии», 
поддержку укрепления и сплочения колективов для выполнения производственных задач. Больщая популярность стенных газет в условиях становления тоталитарного режима объясняется их тесной связью с коллективами, которые выпускали эти газеты и, несмотря на необходимость соблюдения идеологических установок, материалы стенгазет отражали повседневную жизнь коллективов, отличались наличием критических, юмористических и сатирических текстов из повседневной жизни членов коллектива, а также значительным количеством иллюстративного материала.

Ключевые слова: стенные газеты, многотиражные газеты, пресса, периодичность, УССР.

Vakulchuk Olha,

Head of Department, Candidate of Historical Sciences V. Vernadsky National Library of Ukraine

\section{WALL NEWSPAPERS AS A TYPE OF SOVIET LARGE EDITIONS (20-30s of the XX century)}

The purpose of the article is to characterize wall newspapers as a forerunner and form of a particular type of Soviet periodicals - mass-circulation newspapers that appeared in the 1920s and developed in the 1930s in the printed media of the USSR and the UkrSSR during the formation of the totalitarian system. The methodology of the paper is formed by the principle of historicism along with such methods as historical and chronological, comparative, source analysis, and synthesis. The scientific novelty of the paper results in the fact that the study of wall newspapers as a type of Soviet periodicals is carried out for the first time. Conclusions. Wall newspapers as a phenomenon of the Soviet era and operational media emerged in the 1920s and had favorable growth conditions in the 1930s in the printed media of the USSR and the UkrSSR inspired by the ideological scenario of the Soviet government. Supporting the development of wall newspapers, the Soviet government used this type of periodical as an instrument influencing the formation of the consciousness of the Soviet people. It was promoted as a form of activity aimed at creating a socialist state and "socialist democracy" and contributing to the strengthening and cohesion of teams to perform work tasks. The great popularity of wall newspapers in the context of the formation of a totalitarian regime was explained by their strong connection with the collectives issuing these newspapers. Despite the need to comply with ideological principles, wall newspaper contained information about the daily living of collectives, including critical, humorous, and satirical texts related to their lives, as well as significant illustrative material.

Key words: wall newspapers, large edition newspapers, press, periodicity, UkrSSR.

Актуальність теми дослідження. Стінні газети як специфічний вид преси набули найширшого розповсюдження і суспільного значення у радянські часи, процес їх становлення і розвитку припадає на 1920-1930 роки. Підтримуючи розвиток стінних газет, радянська влада надавала цьому виду періодики роль знаряддя впливу на формування свідомості радянських людей і трактувала їх як форму творчої активності мас, один з проявів «соціалістичної демократії». Стінні газети існували повсюдно - на підприємствах, у колгоспах, навчальних закладах, установах, військових частинах. Більшість газет, що виникали як стінні, пізніше переростали у багатотиражні видання. Нині на часі розкриття потенціалу цього сегменту періодики як історичного джерела, а також історико- бібліографічне вивчення стінних і багатотиражних газет, адже залучення якомога більшої кількості джерел сприятиме відтворенню цілісної картини буття України у певний історичний період, зокрема, й 1920-1930-х роки.

Мета статті - охарактеризувати стінні газети як прототип і різновид окремого виду радянської газетної періодики - багатотиражних газет, які виникають у 20-х роках XX ст. і розвиваються у $30-$ - роках у системі друку СРСР та УСРР під час становлення тоталітарної системи.

Аналіз досліджень та публікацій. Стінні газети розглядалися вченими у різних аспектах: як форма прояву соціальної активності молоді (у роботах І. Старкової [2]), як один із видів низової преси у статтях Г. Зав’ялова [12]. 
Про харківські рукописні і друковані стіннівки у контексті культурно-освітнього розвитку УСРР у 20-і pp. ХX ст. йдеться у дисертації К. Шпакович [6], студентську пресу Київського політехнічного інституту досліджувала Г. Лоза [4].

Виклад основного матеріалу. Стінна газета (стінгазета, стіннівка) $є$ прототипом радянських багатотиражних газет, одним з розповсюджених видів інформаційних джерел, що існували 3 найдавніших часів та відображали діяльність різних колективів (трудового, студентського, учнівського, військового підрозділу тощо), надрукована на друкарській машинці, гектографі або написана від руки. Вона відображала основну діяльність колективу та вивішувалася на стіні або спеціальному стенді для оперативного інформування про події у колективі, підтримки «трудового ентузіазму», згуртованості колективів на виконання робочих завдань. За формою та змістом стінні газети близькі до багатотиражних, втім мають деякі відмінності [1]. Однією 3 особливостей стінних газет є їх тісний зв'язок 3 творчою активністю у відображенні повсякденного життя колективів.

Стіннівки не $\epsilon$ винаходом радянської доби, вони як оперативні рукописні інформаційні засоби існували різних формах, починаючи з часів Давнього Риму. Однак найбільшої популярності стіннівки набули саме у радянський період, власне, вони були прообразом багатотиражних газет, проте останні не змогли ïx витіснити, тому ці види преси співіснували паралельно, отримали найширші можливості для розвитку, оскільки не вимагали фінансових затрат і створювалися самими членами колективів. Більшість газет, що виникали як стінні, пізніше переростали у багатотиражні видання.

У роботах радянських істориків поява стінних газет розглядається як результат «творчої ініціативи передових робітників і червоноармійців», «творчої енергії мас». Вважається, що радянську традицію випуску стінгазет започатковано у Москві 28 жовтня 1918 р., коли вийшов перший номер газети РОСТА - «Российского телеграфного агентства». Вже до початку 1920 р. воно мало розгалужену структуру, що складалася з 68 губернських, 50 повітових відділень і понад 500 корпунктів. Окрім основної задачі - забезпечувати пресу і радіо оперативною інформацією, РОСТА видавало газети, журнали, бюлетені, вісники тощо [2]. Губернські і повітові відділення РОСТА постачали інформацію до місцевих органів друку, а також самі видавали «Стінні газети РОСTA», які фактично були новим видом преси. Друкувалися вони на одній стороні і вивішувалися у вітринах або на стінах. Призначалися такі газети для масового читача, тому і готувалися 3 урахуванням цієї особливості: мали великий шрифт, яскраві, виразні заголовки, коротенькі статті.

Стінні газети можна було прочитати буквально на ходу, не зупиняючись і не витрачаючи часу. 3 цих стінгазет пізніше «виросли» популярні «Вікна сатири РОСТА» (в Україні «УКРОСТА»). У 1920 р. вони випускалися у Миколаєві, Одесі, Полтаві, Харкові. Існували і відділення «УКРОСТА», зокрема, в Одесі «ЮГРОСТА і «ОДУКРОСТА». «Вікон» в Одесі випущено понад 1000, вони супроводжувалися ілюстраціями, тексти для них писали радянські поети та письменники, зокрема Е. Багрицький, Ю. Олеша та ін. відомі автори [3, 77-78, 89].

У 1920-i pp. започатковано студентські стінгазети. Так, з травня 1923 р. веде свою історію стіннівка Київського політехнічного інституту «Новый путь», котра одразу завоювала популярність серед студентства і викладачів. Стіннівки в КПІ випускалися на всіх факультетах і навіть у більшості груп. Навколо газет гуртувався студентський актив. Безумовно, виходячи з радянської концепції ідеологічної ролі газети як пропагандиста i агітатора, значна увага приділялася партійному i комсомольському життю інституту, пропаганді марксистко-ленінських ідей, висвітленню партійного курсу, ідеологічному вихованню. Втім, особливою популярністю користувалися гумористичні і сатиричні матеріали, наближені до життя інституту. У 1934 р. з'явилася сатирична газета «Промывалка», над створенням якої працювали талановиті аматори: карикатуристи, фотографи, автори фейлетонів, гумористичних віршів і оповідань. Натхненні прикладом загальноінститутської «Промывалки», в КПІ з'явилися факультетські сатиричні стіннівки «Бегемот», «Индикатор», «Молния», «Шлакосниматель» [4, 1-3]. Такі газети існували не тільки у стінах навчального закладу, але й у студентських гуртожитках. 
Стінгазети, як правило, випускалися 3 періодичністю 1-4 рази на місяць, виготовлялися на аркуші паперу формату A1 редакційною колегією, обраною на загальних зборах колективу, йому ж (колективу) редколегія звітувала про свою роботу. На початку 1920-х років стінгазети випускалися до свят або присвячувалися поточним справам, не було сформульовано і загальних вимог до їх оформлення та змісту.

Однак розвиток тоталітарної системи не залишив без уваги й стінні газети, про що свідчить резолюція ХІІІ з’їзду РКП(б) про завдання друку і постанова Оргбюро ЦК РКП(б) «Про стінні газети» (грудень 1924 р.), де підкреслювалася роль стінгазет у системі друку СРСР як знаряддя впливу на маси і як форма активності цих мас. У постанові йдеться про керівництво, роль, зміст стінгазет, зокрема, виробничих, сільських, військових, студентських. Зверталася увага та тематику статей, вона мала бути безпосередньо пов'язана 3 діяльністю підприємства - виконанням виробничих завдань, інформуванням про технічні досягнення; у разі появи викривальних статей або статей про недоліки, стінгазета мала надати пропозиції щодо їх усунення; стінгазета на селі повинна була висвітлювати питання покращення сільського господарства, кооперації, підвищення культурного рівня села, захисту селян від «куркулів»; обов'язковим визначено і вміщення політичної інформації - «останніх новин». Зазначалося, що статті мають бути короткими і доступними масовому читачеві; керівництво роботою над стінною газетою покладалося на партійні комітети [5, 123-125]. Компартія оголосила стінні газети одним 3 проявів соціалістичної демократії; кожен робітник, службовець, колгоспник міг брати участь у роботі стіннівки свого підприємства.

У середині 1920-х рр. випуск стінгазет набуває масового характеру. Кожне підприємство, цех, бригада, ВНЗ, школа, клуб, театр, армійський підрозділ мали свою стінну газету, з середини 1920-х рр. їх кількість по всьому СРСР наближалася до 100 тис. Наприклад, лише у Харкові у цей період існувало 400 стіннівок, з них 90 - друкованих [6, 10]. Перша 3 харківських щоденних стінних газет виникла на заводі «Серп і молот», серед інших харківських стіннівок варто назвати «Красные крылья», «Клич комсомольца», «К посевной кампании», «До праці», «Доброхим» тощо. Друковані стінгазети випускалися на підприємствах Снакієвого («Голос петровца»), Житомира («Красный вестник»), Кам'янець-Подільського («Голос праці»), Ізюму («Красный пахарь»), Катеринослава («Воздухофлот», «За серп и молот», «В добрый путь!»), Києва («Будильник», «Жовтень», «Голота», «Київський ярмарок», «Красный конвоїр», «Красный печатник»), Коростеня («Красный край), Корсуня («Сднання»), Могилів-Подільського («Клич комсомольца»), Ніжина («Воля і праця»), Одеси («Великий посев», «Красная гранка»), Охтирки («Единый сельхозналог»), Пирятина («Знання і праця»), Умані («Красный полиграфист»). Одна з перших заводських стінгазет з'явилася на Полтавському паровозоремонтному заводі.

Стіннівки широко розповсюджувалися, проникаючи у повсякденне життя не тільки колгоспів, радгоспів, машино-тракторних станцій (МТС), підприємств чи установ, але й окремих цехів, бригад, відділень. У періоди розгортаннязначних господарсько-політичних заходів з'являються численні «Блискавки», «Бойові листки», «Сатиричні сторінки», котрі випускаються щоденно, оперативно інформуючи про хід посівної та збиральної кампаній, про досвід ударників, викриваючи порушників трудової дисципліни і критикуючи вади у роботі. За сигналами стінної преси викривалися і усувалися недоліки, впроваджувалися новації, розроблялися механізми заощадження коштів. Про популярність стіннівок свідчать зусилля, що прикладалися задля їх найширшого розповсюдження. Серед популярних заходів - конкурси всесоюзного, республіканського, міського та ін. рівнів. Чим далі існували стіннівки, тим більше вимог до них висувалося: «крім життя заводу чи цеху, треба в газеті висвітлювати життя країни» - писала у 1937 р. «Більшовицька зброя» [7]. Ця ж газета дорікає редколегіям стіннівок за відсутність критики, особливо щодо адміністрації, боязнь викривати недоліки, пасивне ставлення до роботи у стінгазеті тощо [8].

У 1920-х - 1930-х роках гостро відчувалася нестача фахівців, які б на належному 
рівні готували газети, проблема професійної підготовки редакторів залишалася актуальною і наприкінці 1930-х рр. Так, у журналі «В помощь районной газете и многотиражке» (червень 1937 р.) зазначалося, що у складі редакторів більшість 3 недостатньою освітою та політичною підготовкою, тому партійні органи зобов'язані зайнятися організацією освіти редакторів стінних газет [9]. Деякі районні газети за власною ініціативою друкували спеціальні сторінки «На допомогу редактору стінної газети», де надавалися поради і містилися відповіді на основні питання, що виникали у процесі підготовки стінгазети, зокрема: як оволодіти технікою газетної справи, яким має бути заголовок і як працювати над підвищенням свого рівня знань. Так, досвідчені редактори радили використовувати короткі, чіткі, «політично грамотні» заголовки: «Якщо неграмотність у тексті неприпустима, то в заголовку вона $є$ тричі неприпустимою», вміщувати у стінгазетах фотоілюстрації, малюнки, карикатури [10]. Для допомоги редакторам стінгазет організовувалися курси, практичні заняття, навчання, проводилася робота з авторами.

У процесі свого розвитку стіннівки часто перетворювалися на друковані багатотиражки, залишивши при цьому не тільки ту саму назву, але й валову нумерацію. Наприклад, «Аго-прес» - орган робітників та службовців київської фабрики взуття, «Блискавка трамваю» - орган робітників та службовців Одеського трамваю, «Вал» - орган партколективу і завкому Державного заводу «Інтернаціонал» (Запоріжжя) - багатотиражні газети, що спочатку існували як стінні і в подальшому зберегли їх валову нумерацію. Про такі перетворення часто писали самі багатотиражки. Наприклад, редакційна стаття «Як виросла наша стінгазета в багатотиражку» (газета робітників та службовців Київського заводу імені Артема «Молот») розкриває історію цього видання: однойменну стіннівку вирішено перетворити на друковану багатотиражку за ініціативою нової редколегії і парторганізації у червні 1929 р. Валова нумерація газети збереглася і велася від стінгазети 3 тією ж назвою - «Молот», що виходила на підприємстві з 1923 р.

Стінні газети перебували під постійною увагою і опікою з боку партійних органів, їм відводилася роль органів «широкої самодіяльності мас» $[11,184]$. 3 самого початку компартія розглядала стінні газети як важіль впливу на маси, важливу ділянку організаційної та ідеологічної роботи. В офіційних документах зазначалося: «партийные комитеты должны помогать, содействуя редакциям в организации семинариев для стенгазетчиков, бюро рецензий, выставок стенгазет и пр.» $[11,185]$. Стіннівки поступово міцно затверджувалися в суспільно-політичному і виробничому житті підприємств, колгоспів, установ. Характеризуючи стіннівки, письменник М. Горький писав: «Создана совершенно своеобразная пресса, до пустяковых мелочей быта внимательная к жизни робочих и крестьян. Может быть не меньшее культурное и политическое значение, чем большие газеты столиц имеют бесчисленные маленькие газетки, которые издаються робочими фабрик, типографий, трамваев... газетки, в которых сами рабочие учатся писать по вопросам быта, вопросам развития продуктивности труда и где самокритика робочих красноречиво говорит о повышении их чувства собственного достоинства, о росте их культурных запросов, о стремлении к знанию» $[12,3-4]$.

У 1930-х рр. стіннівки випускалися повсюдно. Часто ця робота виконувалася як обов'язкове «громадське навантаження». Про стінгазету Комуністичного газетного технікуму імені М. Островського згадує Юрій Шевельов: «Мав я «громадське навантаження». У технікумі я робив стінгазету. Виходила вона двічі на рік... статті й інші матеріали писав або збирав я: я наклеював їх шпальтами на великий аркуш паперу; хто вмів малювати, - робив малюнки, дружні шаржі, карикатури, що ix наліплювано між дописами, i все це вивішувано на загальне читання. Завданням стінгазет було підносити ударників, висвітлювати їхній досвід і викривати «хвостистів», відсталих і консервативних, але під моїм проводом наголос був на першому» $[13,271]$. Пізніше, у 1950-і рр. практика «наліплювання» зображень на аркуш набула професійного підходу, коли редакція журналу «Перець» почала друкувати серії плакатів 3 малюнками, спеціально призначених для підготовки стінгазет. У редакційній «інструкції» 3 застосування таких малюнків зазначено, що їх «...треба вирі- 
зувати з цього аркуша й наклеювати на стінні газети, «Бойові листки», сатиричні додатки до стінних газет. В тексти під карикатурами вписуйте прізвища конкретних винуватців... неподобства, людей, що стоять на заваді в успішному проведенні сільгоспробіт, порушують Статут сільгоспартілі» [14].

Наприкінці 1920-х - на початку 1930-х рр. міськкомами, райкомами КП(б)У, редакціями міських і районних газет складалися списки стінних і багатотиражних газет (окремо «робітничих», військових, виробничих цехових, залізничних, колгоспних, установ, хат-читалень тощо) по районах і надсилалися до відділу пропаганди і агітації ЦК КП(б)У (такі списки збереглися у Центральному державному архіву громадських об'єднань України, далі - ЦДАВО). Найчастіше це були статистичні дані, іноді, окрім кількості газет, надавався перелік назв. Наприклад, список стінгазет Артемівської округи, до якої входили Горлівський, Гришинський, Єнакіївський, Залізнянський, Костянтинівський, Лисичанський, Олександрівський, Петрівський райони (всього 15), містить розлогу інформацію щодо назв стіннівок, періодичності виходу, кількості екземплярів і робкорів, які беруть участь у цій роботі [15].

Більшість газет випускалися на заводах, шахтах і копальнях. Наприклад: на Горлівських копальнях №5 і №8 виходили стіннівки «Шахтёрское око», «Луч правды», «Юный коммунар»; на Гришинських шахтах №1 i №8 - «Юношеская мысль», «Юный комсомол», «Ленинец»; при Лисичанському заводі «Донсода» - «Голос содовца», «Вперёд», «Знамя ленинца»; при Петрівському робклубі - «Голос Ленина», «Красный клич», «Стрелка»; на залізничній станції Горлівка - «Транспорт», на станції Гришино - «Транспортник» та «Молодой транспортник»; на Залізнянському заводі імені Калініна - «Маяк молодёжи»; при Костянтинівському райсельбудинку - «Красный пахарь»; при Гришинському радгоспі «Горняк» - «Юный рабочий» тощо. Деякі стіннівки не мали назви [15].

Крім «загальних» стіннівок, що виходили на промислових підприємствах і будівництвах, у колгоспах і радгоспах, військових частинах, наукових установах, театрах, залізничних станціях, ліспромгоспах тощо, випускалися цехові, бригадні, факультетські тощо; подекуди такі газети виготовлялися щоденно, як, наприклад, «Вагранка» - цехова стіннівка, що виходила на Харківському заводі «Серп і молот». Про цей різновид стінних газет на своїх сторінках пише «Тяговик» (Київ, 1929): «Сам факт, що в цеху $є$ стінгазета, каже за політичне й культурне піднесення робітничої маси цього цеху. Редколегія газети «Тяговик», вітаючи гарний почин ... допоможе в керівництві й прикладе всіх зусиль, щоб стінгазету в цеху закріпити» [16].

На шахтах існували бригадні, т. зв. «підземні стінгазети», такі, як: «На штурм», «За уголь», «За механизацию», «Врубовка», «Непрерывный вруб». На нараді редакторів підземних газет Кадієвського району спільно з редакцією газети «Пролетар», що відбулася у червні 1931 р., обговорювалося питання про перший досвід і перші результати роботи редакцій цих стіннівок. Відзначено, що шахтні бригадні стінні газети успішно ведуть боротьбу з симулянтами, прогульниками і ледарями i, як результат прогулів поменшало, дисципліна покращилася i, відповідно, покращилися показники праці. Нарада завершилася висновками про необхідність виходу підземних газет у кожній зміні, збільшення їх кількості і покращення якості організації робкорівських бригад [17].

Вважалося, що стінгазети сприяють покращенню роботи підприємств, цехів, колгоспів, ВНЗ тощо. На сторінках стіннівок розгорталася кампанія проти прогулів, пияцтва, інших вад і недоліків, містилися огляди культмасової роботи тощо. Іноді редактори стіннівок вдавалися до незвичайних заходів задля урізноманітнення роботи. Так, одна із запорізьких газет влаштувала виставку бракованих речей і підготувала огляд «Музей браку» [18].

Про успіхи стінгазет у справі перевиховання прогульників, п'яниць і «відстаючих» писали навіть центральні газети. Так, «Коммунист» у № 99 за 1925 р. у рубриці «Газета на стене» надрукувала розповідь про сім'ю Соболєвих - нещасну дружину і чоловікап'яницю. Жінка перебрала усі можливі засоби впливу - зверталася до керівництва заводу, у жінвідділ, але марно. I тут вночі вона згадала про стінгазету, «взяла олівець і почала писати: допоможіть, дорогий товаришу редактор». Напевно, це спрацювало, чоловік прийшов до- 
дому тверезий, віддав «получку». А Соболєва усім розповідала: «завком не допоміг, жінвідділ не допоміг, а стінгазета допомогла!» [19]. Додамо, що подібних матеріалів у тогочасних газетах можна знайти чимало.

Газета «Коммунист» у № 205 за 1924 р. у рубриці «По столбцам стенгазет» помістила матеріал про стіннівку харківського електромеханічного заводу (ВЕК) «Красный ток». Серед недоліків газети відзначено дрібний шрифт і нерозбірливість тексту, а велика за обсягом, малозрозуміла передова стаття не викликає бажання дочитати i до кінця. Зазначається, що писати треба маленькі статті, засновані на конкретних фактах, що мають місце на даному підприємстві, але головне «писати розбірливо, так, щоб газету міг прочитати навіть лікнепник» (лікнеп - ліквідація неписьменності - O.B.). Далі йдеться про позитивні моменти у роботі газети, пов'язані зі змістом решти дописів щодо виробничих і побутових питань: «Немиті рушники і зниклі чашки відійшли далеко, їх замінили проблеми продуктивності праці, зменшення видатків, безгосподарність [20]. Про контроль стіннівок з боку центральних газет свідчить і надрукований у «Пролетарській правді» (№ 29 за 1930 р.) критичний матеріал про стінгазету київської штампувальної фабрики Металотресту, яка, за словами автора допису «пасе задніх у виробничому житті підприємства», не висвітлює «великі завдання, які розв'язує робітнича кляса, як... боротьба з втратами, виконання промфінплану...» [21]. Автор допису вважає, що до такого сумного стану призвело ігнорування газети з боку партосередку та завкому.

3 розвитком стіннівок, вони вже не обмежувалися висвітленням окремих фактів 3 життя певного підприємства чи установи. Поволі ці газети починали вміщувати матеріали ширшого змісту: раціоналізація та покращення виробництва, індустріалізація, державна позика тощо. На початку 1920-х рр. стінна преса була наймасовішою.

Варто сказати, що наприкінці 1920-х рр. кількість стіннівок досягла такої кількості, що майже не піддавалася обліку. У 1928 р. під час підготовки Всеукраїнської робсількорівської наради, була спроба їх порахувати, проте вона виявилася невдалою: «Досі не можна встановити точного числа стінгазет на Україні, бо загального, повного обліку не вдалося зробити» [22]. I нині порахувати кількість цих газет, облікувати їх, скласти бібліографію практично неможливо.

18 січня 1931 р. вийшла чергова постанова ЦК ВКП(б), де наголошується на необхідності розгортання мережі стінгазет у всіх колгоспах, радгоспах, МТС, у кожному населеному пункті за умови «обов'язкового забезпечення партійного керівництва ними» $[5,173]$. Машинотракторні станції масово розпочали свою роботу у 1929 р. після оприлюднення постанови Ради праці та оборони СРСР «Про організацію МТС» (5 червня 1929). На кінець літа 1929 р. в УСРР діяли 35 державних, кооперативних і колгоспних МТС. Для широкого розголосу настанови про необхідність і важливість діяльності МТС ЦК ВКП(б) 16 жовтня 1930 р. прийняв спеціальну постанову «Об освещении работы машинотракторных станций», у якій перед центральною і місцевою пресою чітко поставлене завдання широко висвітлювати роботу МТС, залучаючи до цієї справи маси низових працівників МТС та колгоспний актив, а редакціям газет «Правда», «Известия», Комсомольская правда», «Социалистическое земледелие» (орган Наркомземів СРСР та РРФСР, Колгоспцентру та Зернотресту) регулярно, раз на декаду, розміщувати матеріали про роботу «Всесоюзного центру машино-тракторних станцій» («Трактороцентр») та МТС. 3 розвитком МТС підвищувалася культура землеробства; керівництво держави розглядало МТС як найраціональнішу на той час форму технічного переоснащення сільського господарства і визначало провідну роль МТС у соціальноекономічному розвитку села.

У січні 1933 р після пленуму ЦК ВКП(б) при МТС започатковано політвідділи, задача яких - партійний контроль в усіх галузях роботи колгоспів, радгоспів, МТС, у тому числі, i випуску газет. За даними дослідника аграрних відносин в Україні В. І. Марочка у 1932 р. діяло 592 МТС. Можна припустити, що кількість стінних газет дорівнювала або перевищувала кількість МТС, адже стіннівки випускалися i в окремих бригадах.

Стіннівки були дуже популярні і надалі. Для їх підтримки і популяризації з 60-х ро- 
ків випускалися серії плакатів «На допомогу стінгазетам». Здебільшого - це карикатури, що готувалися групою художників-сатириків, які співпрацювали 3 відомим українським ілюстрованим сатирично-гумористичним журналом «Перець», який видавався у Харкові 31922 р. Серії таких плакатів випускалися для робкорів і сількорів, котрі використовували їх «на місцях» при підготовці стінгазет [23, 25]. У 1970-ті роки стінгазети набули такої популярності, що їх кількість сягала майже 2 млн. включно з оперативними додатками до них - «бойовими», «сатиричними» листками, «блискавками» тощо. Велика радянська енциклопедія зазначає, що у процесі виготовлення стінних газет у цей період задіяні десятки мільйонів людей як автори чи учасники робсількорівських рейдів [24, 483].

Висновки. Стіннівки як явище радянської доби, оперативні інформаційні засоби виникли у 20 -х роках XX ст. та розвивається у 30-х роках у системі друку СРСР та УСРР за ідеологічним сценарієм радянської влади.
Стінні газета як «низова преса» набули значення одного з дієвих засобів впливу радянської влади на масову свідомість пересічних громадян, вони відігравали роль знаряддя пропаганди ідей компартії, «виховання трудящих у дусі соціалістичної свідомості», «високих моральних якостей радянської людини» на прикладах з повсякденного життя свого підприємства, радгоспу, колгоспу, школи, університету, установи чи організації. Стіннівки розвивали форму активності, спрямовану на підтримку зміцнення та згуртованості колективів для виконання виробничих завдань. Велика популярність стінних газет в умовах становлення тоталітарного режиму пояснювалася їх тісним зв'язком з колективами, які випускали ці газети, і які, попри наявність обов'язкового ідеологічного матеріалу, містили інформацію про повсякденне життя колективів, містили привабливі матеріали критичного, гумористичного і сатиричного характеру, наближені до життя колективів, значний ілюстративний матеріал.

\section{Список використаних джерел}

1. Вакульчук О. А. Багатотиражні газети України: створення, функціонування, характерні особливості. Рукописна та книжкова спадщина України, 2018. Вип. 22. С. 67-82.

2. Старкова И. Стенная газета как форма проявления и средство развития социальной активности молодежи Удмуртии в 20-е гг. ХХ в. Учёные записки Казанского гос. университета. Том 151. Кн. 5. Ч. 2. Казань, 2009. С. 191-200.

3. Бутник-Сиверский Б. С. Советский плакат эпохи гражданской войны. 1918-1921. Москва, 1960. 695 с.

4. Лоза Галина. Студентська преса Київського політехнічного інституту (1923-1937). Вісник Книжкової палати, 2011. № 7. С. 1-3.

5. О партийной и советской печати, радиовещании и телевидении. Москва, 1972. 635 с.

6. Шпакович К. В. Культурно-освітній розвиток УСРР 1920-х рр. (за матеріалами Харківської періодики). Автореф. дис. ... канд. іст. наук. Київ, 2016. 20 с.

7. Лущік. Не цікава стінгазета. Більшовицька зброя, 1937. 27 лютого.

8. Азархіна Р. Кущова нарада редколегій стінгазет. Більшовицька зброя, 1937. 6 березня.

9. Попов П. По-большевистски руководить низовой печатью. В помощь районной газете и многотиражке, 1937. №3.

10. Я-Й. В помощь редактору стенной газеты. В помощь районной газете и многотиражке, 1937. № 2.

11. Советская печать в документах. Москва, 1961. 560 с.

12. Завьялов Г. Стенная и многотиражная печать. Алма-Ата, 1957. 60 с.

13. Шевельов Ю. Я - мене-мені... (і навкруги). Спогади. 1. В Україні. Харків, 2017. 695 с.

14. Плакат з фондів Відділу образотворчого мистецтва НБУВ.

15. Список издаваемых стенных газет по Артёмовскому округу. ЦДАГО, ф. 1, оп. 20, спр. 7515: арк. 16-18.

16. Максименко. Вітаємо цехові стінгазети. Тяговик, 1929. 7 листопада.

17. ЦДАГО, ф. 1, оп. 20, спр. 4184, арк. 166-170.

18. ЦДАГО, ф.1.оп. 20, спр. 2699, арк. 133. 
19. Фельдман. Стенгазета помогла. Коммунист. Харьков, 1925. 5 мая.

20. М. М. По столбцам стенгазет. Коммунист, 1924. 7 сентября.

21. І. Ф-с. Ігнорують стінгазету. Пролетарська правда, 1930. 5 лютого.

22. ЦДАГО, ф. 1. оп. 20, спр. 2699, арк. 132.

23. Галькевич Т., Донець О. Український друкований плакат 1950-1964 pp. $з$ фондів НБУВ : каталог. Вип. 1. Київ, 2014. 424 с. : іл.

24. П. А. Чернущенко. Стенная газета. БСЭ. Москва, 1975. Т. 24. С. 483.

\section{References}

1. Vakulchuk O. A. (2018) Mass-circulation newspapers of Ukraine: creation, functioning, peculiarities. Manuscript and book heritage of Ukraine, Issue 22, 67-82. [in Ukrainian].

2. Starkova I. (2009) Wall newspaper as a form of manifestation and mean of developing the social activity of the youth of Udmurtia in the 1920s of the XX century. Scientific notes of the Kazan State University. Volume 151, Book. 5, Chapter 2, Kazan, 191-200. [in Russian]

3. Butnik-Siversky B.S. (1960) Soviet poster of the Civil War era. 1918-1921. Moscow, 695 p. [in Russian]

4. Loza Halyna. (2011) Student Press of the Kyiv Polytechnic Institute (1923-1937). Bulletin of the Book Chamber, № 7, 1-3. [in Ukrainian].

5. On the party and Soviet press, radio and television. Moscow, 1972. $635 \mathrm{p}$.

6. Shpakovych K.V. (2016) Cultural and educational development of the UkrSSR in the 1920s (according to the Kharkiv periodicals). Author's ref. dis. ... Cand. Of Historical Sciences. Kyiv, 20 p. [in Ukrainian].

7. Lushchik. (1937). Not interesting wall newspaper. Bolshevik weapons,. February 27 [in Russian].

8. Azarkhina R. (1937). Industry meeting of the editorial boards of wall newspapers. Bolshevik weapons, March 6 [in Russian].

9. Popov P. (1937). How to lead the grassroots press in a Bolshevik. A guide for the district newspaper and mass-circulation periodicals, №3[in Russian].

10. I- J. (1937). A guide for the editor of the wall newspaper. A guide for the district newspaper and masscirculation periodicals, 2. [in Russian].

11. Soviet press in documents. (1961). Moscow, [in Russian].

12. Zavyalov G. (1957). Wall and mass printing. Alma-Ata [in Russian].

13. Shevelyov Y. (2017) I - me-me... (and around). Memoirs. 1. In Ukraine. Kharkiv [in Ukrainian].

14. Poster from the archives of the Department of Fine Arts of V. Vernadsky National Library of Ukraine.

15. List of published wall newspapers in the Artyomovsky district. Central State Archive of Public Associations, f. 1, op. 20, file no. 7515: p. 16-18.

16. Maksimenko. Congratulations to the workshop wall newspapers. Tyahovyk, 1929. November 7.

17. Central State Archive of Public Associations, f. 1, op. 20, file no. 4184, p. 166-170.

18. Central State Archive of Public Associations, f.1.op. 20, file no. 2699, p. 133.

19. Feldman. The wall newspaper helped. Communist. Kharkiv, 1925. May 5.

20. M. M. In the columns of the wall newspapers. Communist, 1924. September 7.

21. I. F-s. Ignoring the wall newspaper. Proletarian Truth, 1930. February 5.

22. Central State Archive of Public Associations, f. 1, op. 20, file no. 2699, p.132

23. Halkevych T., Donets O. The Ukrainian printed poster of 1950-1964s from the archived of V. Vernadsky National Library of Ukraine: catalogue. Issue 1. Kyiv, 2014. 424 p. : il. [in Ukrainian].

24. P. A. Chernushchenko. Wall newspaper. GSE. Moscow, 1975. V. 24. p. 483. 